\title{
Ultrastructural Study of Uterine Natural Killer Cells Found in Pregnant, Interleukin-2 Receptor $\beta$-chain Overexpressed Transgenic Mice
}

\author{
Keiji KOKUBU ${ }^{1)}$, Eiichi HONDO ${ }^{1,2)}$, Yasuharu NAMBA ${ }^{1)}$, Ken KUSAKABE ${ }^{3)}$, \\ Eiji SAGARA $^{4)}$ and Yasuo KISO ${ }^{1,2)}$ \\ ${ }^{1)}$ The United Graduate School of Veterinary Science, ${ }^{2)}$ Department of Veterinary Anatomy, \\ Faculty of Agriculture, Yamaguchi University, 1677-1 Yoshida, Yamaguchi 753-8515, \\ ${ }^{3)}$ Department of Anatomy and Biology, Osaka Medical College, Takatsuki 569-8686, and \\ 4) Animal Research Center, Kyushu Dental College, Kokurakita-ku, Kitakyushu 803-8580, Japan
}

\begin{abstract}
We previously reported that all fetuses died or were resorbed on day 12 of pregnancy (Day $1=$ the day of plug) in interleukin-2 (IL-2) receptor $\beta$-chain overexpressed transgenic $(\mathrm{Tg} 2 \mathrm{R} \beta)$ mice. In this study, to clarify the role of uterine natural killer (uNK) cells in pregnancy, the ultrastructure of $\operatorname{Tg} 2 \mathrm{R} \beta$ mouse uNK cells was analyzed using a transmission electron microscope. uNK cells and their granules on day 10 of pregnancy were larger in $\operatorname{Tg} 2 \mathrm{R} \beta$ mice than control mice, indicating that differentiation of uNK cells in $\operatorname{Tg} 2 \mathrm{R} \beta$ mice progressed rapidly. Additionally, the granules of $\mathrm{uNK}$ cells in $\operatorname{Tg} 2 \mathrm{R} \beta$ mice on day 10 of pregnancy had an irregular morphology. The multivesicular regions were present in the cap structure of these granules, suggesting that the uNK cells of the $\operatorname{Tg} 2 \mathrm{R} \beta$ mice had cytotoxic activity.

Key words: Interleukin-2 receptor $\beta$-chain overexpression, Transgenic mouse, Uterine natural killer (uNK) cell, Ultrastructure
\end{abstract}

(J. Reprod. Dev. 51: 695-698, 2005)

\begin{abstract}
Naria urine uterine natural killer (uNK) cells dramatically increase in number and size from day 8 to 12 of pregnancy, and decrease from day 14 onward $[1,2]$. The function of $\mathrm{uNK}$ cells remains to be fully defined. In tge 26 mice deficient in $\mathrm{uNK}$ cells $\left(\mathrm{T}^{-} / \mathrm{B}^{+} / \mathrm{NK}^{-}\right)$, female reproductive performance during pregnancy was quite poor. After reconstitution of $\mathrm{uNK}$ cells with bone marrow cells derived from scid/scid mice $\left(\mathrm{T}^{-} / \mathrm{B}^{-} / \mathrm{NK}^{+}\right)$, fetal viability in tge26 mice recovered $[3,4]$, which clearly indicates that $\mathrm{uNK}$ cells play important roles in successful gestation. However, we cannot rule out the possibility that uNK cells can cause

Accepted for publication: July 4, 2005

Published online: August 29, 2005

Correspondence: E. Hondo (e-mail: ehondo@yamaguchi-u.ac.jp)
\end{abstract}

abortion, since NK cells differentiate into lymphokine activated killer (LAK) cells through interleukin (IL)-2 stimulation, and since LAK cells can attack trophoblasts [5]. Indeed, uNK cells express IL-2 receptor, thus uNK cells could differentiate into LAK cells and have cytotoxity for trophoblasts [6, 7]. We previously reported that severe abortion occurred in the IL-2 receptor $\beta$ chain overexpressed transgenic $(\operatorname{Tg} 2 \mathrm{R} \beta)$ mice $[8,9]$. In $\operatorname{Tg} 2 \mathrm{R} \beta$ mice, all fetuses were lost on day 12 of pregnancy. The $\mathrm{uNK}$ cells of $\operatorname{Tg} 2 \mathrm{R} \beta$ mice invaded into the labyrinthine zone. This invasion of $\mathrm{uNK}$ cells is not observed in normal mice. Therefore, the uNK cells of $\operatorname{Tg} 2 \mathrm{R} \beta$ mice might have cytotoxity for trophoblasts. In the present study, to clarify the role of $\mathrm{uNK}$ cells in pregnancy, the uNK cells of 


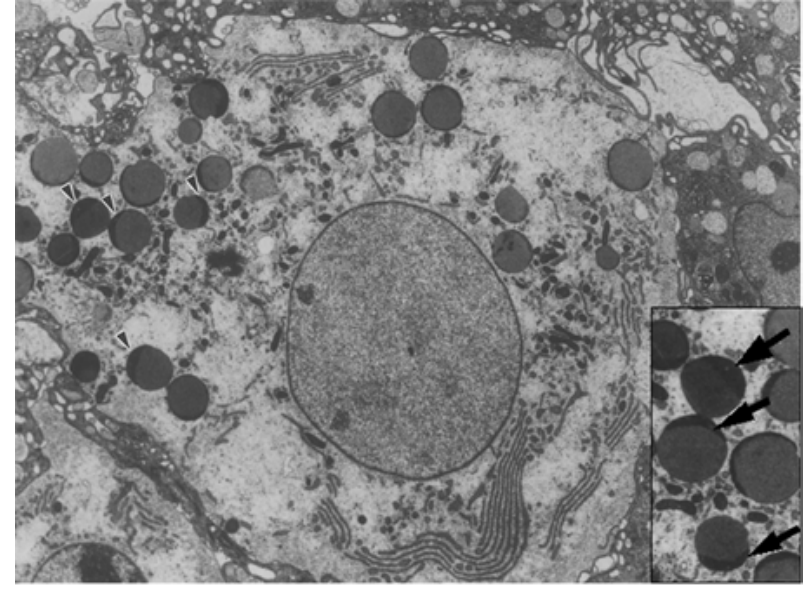

Fig. 1. Ultrastructure of uNK cells in NL - control mouse on day 12 of pregnancy. The uNK cells contain circular granules in the cytoplasm. These granules have a cap structure with a uniform electron density (arrow head). $(\times 5,000)$ Inset: The cap structure (arrows) has a regular shape and uniform electron density. $(\times 7,000)$

$\operatorname{Tg} 2 \mathrm{R} \beta$ mice were analyzed by transmission electron microscopy (TEM).

\section{Materials and Methods}

\section{Mice}

To obtain $\operatorname{Tg} 2 \mathrm{R} \beta$ mice, C57BL $/ 6$ females were mated with $\operatorname{Tg} 2 \mathrm{R} \beta$ males. Reverse transcriptionpolymerase chain reaction (RT-PCR) using mRNA from the peripheral blood was used to confirm whether or not transgenesis was successful in the next generation of mice (data not shown) [10]. The primers used were as follows: the sense primer was 5'-AATGTCTCTTGCATGTGGAG-3' and the antisense primer was 5'-AGACGCAGGAGAAGAAG-3'. Subsequently, female $\operatorname{Tg} 2 \mathrm{R} \beta$ mice were mated with syngeneic males. Normal littermates (NL) without overexpression of IL-2 receptor $\beta$ chain were used as controls. All animal experiments were conducted according to the Guide for the Care and Use of Laboratory Animals of Yamaguchi University.

\section{Ultrastructural studies}

For TEM observation, the decidua basalis of $\operatorname{Tg} 2 \mathrm{R} \beta$ mice and NL (day 10 and 12) was fixed in $2.5 \%$ glutaraldehyde and $2 \%$ paraformaldehyde/

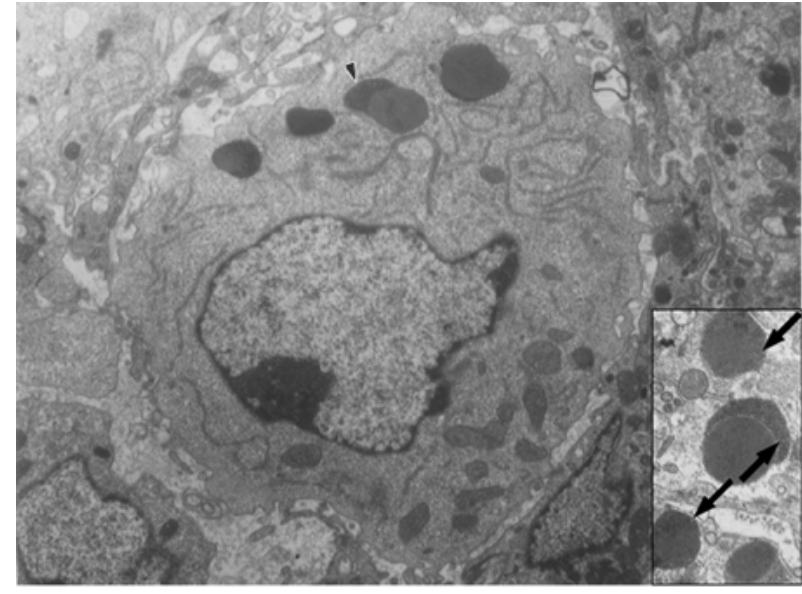

Fig. 2. Ultrastructure of uNK cells in a $\operatorname{Tg} 2 \mathrm{R} \beta$ mouse on day 10 of pregnancy. The cytoplasmic granules in the $\operatorname{Tg} 2 \mathrm{R} \beta$ mouse are irregular in shape and have a cap structure that is also irregular in shape (arrow head). The cap structure in $\operatorname{Tg} 2 \mathrm{R} \beta$ mice has a low electron density compared to NL. $(\times 5,000)$ Inset: Multivesicular regions (arrows) are present in the cap structure of these granules. $(\times 7,000)$

0.1 M phosphate buffer ( $\mathrm{pH}$ 7.4). Postfixation was performed in $1.5 \%$ osmium tetroxide in the same buffer. After dehydration with a graded series of ethanol and infiltration by propylene oxide, specimens were embedded in epoxy resin (Polysciences, Inc., Warrington, PA, USA). Ultrathin sections, $90 \mathrm{~nm}$ thick, were prepared and analyzed by TEM (H-7600L; Hitachi, Ibaraki, Japan).

\section{Results}

The uNK cells of $\operatorname{Tg} 2 \mathrm{R} \beta$ mice and those of NL extended cytoplasmic processes that reflected on the ability of cells to migrate. Although uNK cell of NL contained small granules on day 10 of pregnancy, they had large and circular granules with a cap structure on day 12 of pregnancy (Fig. 1). However, on day 10 of pregnancy for $\operatorname{Tg} 2 \mathrm{R} \beta$ mice, $\mathrm{uNK}$ cells and their granules were larger than those of NL on the corresponding day. The uNK cells on day 10 of pregnancy for $\operatorname{Tg} 2 \mathrm{R} \beta$ mice were the same size as those on day 12 of pregnancy for $\mathrm{NL}$, i.e., approximately $35-40 \mu \mathrm{m}$ in diameter. The granules of $\operatorname{Tg} 2 \mathrm{R} \beta$ mice on day 10 of pregnancy were irregular in shape, with a cap structure different from that in NL. The cap structure of $\operatorname{Tg} 2 \mathrm{R} \beta$ mice 
on day 10 of pregnancy contained multivesicular regions and was enlarged in comparison with that of NL. (Fig. 2).

\section{Discussion}

The size of the $\mathrm{uNK}$ cells of $\operatorname{Tg} 2 \mathrm{R} \beta$ mice on day 10 of pregnancy were similar to those of NL on day 12 of pregnancy, suggesting that differentiation of $\mathrm{uNK}$ cells in $\operatorname{Tg} 2 \mathrm{R} \beta$ mice progressed more rapidly than in NL. Such morphological changes could be caused by stimuli through the overexpressed IL-2 receptor $\beta$-chain. It is possible that not only IL-2, but also other cytokines, could be involved in the rapid differentiation of $\mathrm{uNK}$ cells in $\operatorname{Tg} 2 \mathrm{R} \beta$ mice since pregnancy in IL-2 knockout mice is normally maintained and their uNK cells can normally differentiate $[11,12]$. IL-15 is a candidate to accelerate differentiation of $\mathrm{uNK}$ cells in $\operatorname{Tg} 2 \mathrm{R} \beta$ mice because of its high affinity to the IL-2 receptor $\beta$-chain $[13,14]$. This is also supported by the report that human decidual NK cells analogous to murine uNK cells were activated by IL-15 [15]. The $\mathrm{uNK}$ cells of $\operatorname{Tg} 2 \mathrm{R} \beta$ mice showed several different features compared to NL, i.e., enlargement of cytoplasmic granules with perforin and/or granzymes [16-19], and granules and a cap structure with an irregular shapes. The presence of the multi-vesicular region in the cap structure of cytoplasmic granules in the $\mathrm{uNK}$ cells of $\operatorname{Tg} 2 \mathrm{R} \beta$ mice suggests, that according to morphological criteria, these were releasing type cells and that they had cytotoxic activity [20]. The uNK cells of Tg2R $\beta$ mice might release perforin-enriched granules during mid-pregnancy earlier than NL, and perforin might be cytotoxic to trophoblastic giant cells, allowing uNK cells to invade the labyrinthine zone and ultimately cause abortion.

\section{Acknowledgements}

This study was supported by a Grant-in-Aid for Scientific Research (A, No. 12306015, to Y.K.) and a Grant-in-Aid for Young Scientists (B, No. 16780204, to E.H.) from the Name changed to Ministry of Education, Culture, Sports, Science and Technology in 2001 of Japan.

\section{References}

1. Kusakabe K, Okada T, Sasaki F, Kiso Y. Cell death of uterine natural killer cells in murine placenta during placentation and preterm periods. J Vet Med Sci 1999; 61: 1093-1100.

2. Croy BA, Kiso Y. Granulated metrial gland cells: a natural killer cell subset of the pregnant murine uterus. Microsc Res Tech 1993; 25: 189-200.

3. Guimond MJ, Wang B, Croy BA. Engraftment of bone marrow from severe combined immunodeficient (SCID) mice reverses the reproductive deficits in natural killer cell-deficient tg epsilon 26 mice. J Exp Med 1998; 187: 217-223.

4. Ashkar AA, Di Santo JP, Croy BA. Interferon gamma contributes to initiation of uterine vascular modification, decidual integrity, and uterine natural killer cell maturation during normal murine pregnancy. J Exp Med 2000; 192: 259-270.

5. Drake BL, Head JR. Murine trophoblast can be killed by lymphokine-activated killer cells. J Immunol 1989; 143: 9-14.

6. Croy BA, Guimond MJ, Luross J, Hahnel A, Wang $B$, van den Heuvel M. Uterine natural killer cells do not require interleukin-2 for their differentiation or maturation. Am J Reprod Immunol 1997; 37: 463-470.
7. King A, Loke YW. Human trophoblast and JEG choriocarcinoma cells are sensitive to lysis by IL-2stimulated decidual NK cells. Cell Immunol 1990; 129: 435-448.

8. Namba $Y$, Hondo E, Morimoto M, Nakamura O, Kusakabe K, Ito M, Saito S, Sagara E, Kiso Y. A study of reproductive performance in pregnant, IL-2 receptor $\beta$-chain overexpressed transgenic mice. J Vet Med Sci 2001; 63: 99-101.

9. Kiso Y, Namba Y, Kusakabe K, Makita T. Different aspects of uterine NK cell function at the Feromaternal interface. In: The Ministry of Agriculture Forestry and Fisheries of Japan (eds.), Cloned Animal and Placentation. Tokyo: Yokendo Ldt; 2000: 83-85.

10. Suwa H, Tanaka T, Kitamura F, Shiohara T, Kuida K, Miyasaka M. Dysregulated expression of the IL2 receptor beta-chain abrogates development of NK cells and Thy-1+ dendritic epidermal cells in transgenic mice. Int Immunol 1995; 7: 1441-1449.

11. Greenwood JD, Minhas K, di Santo JP, Makita M, Kiso Y, Croy BA. Ultrastructural studies of implantation sites from mice deficient in uterine natural killer cells. Placenta 2000; 21: 693-702. 
12. Guimond $\mathbf{M}$, Wang $\mathbf{B}$, Croy BA. Immune competence involving the natural killer cell lineage promotes placental growth. Placenta 1999; 20: 441450.

13. Tagaya Y, Bamford RN, DeFilippis AP, Waldmann TA. IL-15: a pleiotropic cytokine with diverse receptor/signaling pathways whose expression is controlled at multiple levels. Immunity 1996; 4: 329_ 336.

14. Ye W, Zheng LM, Young JD, Liu CC. The involvement of interleukin (IL)-15 in regulating the differentiation of granulated metrial gland cells in mouse pregnant uterus. J Exp Med 1996; 184: 24052410.

15. Verma S, Hiby SE, Loke YW, King A. Human decidual natural killer cells express the receptor for and respond to the cytokine interleukin 15. Biol Reprod 2000; 62: 959-968.

16. Parr EL, Young LH, Parr MB, Young JD. Granulated metrial gland cells of pregnant mouse uterus are natural killer-like cells that contain perforin and serine esterases. J Immunol 1990; 145: 2365-2372.

17. Zheng LM, Ojcius DM, Liu CC, Kramer MD, Simon MM, Parr EL, Young JD. Immunogold labeling of perforin and serine esterases in granulated metrial gland cells. FASEB J 1991; 5: 7985.

18. Zheng LM, Liu CC, Ojcius DM, Young JD. Expression of lymphocyte perforin in the mouse uterus during pregnancy. J Cell Sci 1991; 99: 317323.

19. Parr EL, Parr MB, Young JD. Localization of a poreforming protein (perforin) in granulated metrial gland cells. Biol Reprod 1987; 37: 1327-1335.

20. Burkhart JK, Hester S, Lapham CK, Argon Y. The lytic granules of natural killer cells are dual-function organelles combining secretory and pre-lysosomal compartments. J Cell Biol 1990; 111: 2327-2340. 